\title{
INTRASPECIFIC VARIATIONS STUDIED BY ISSR AND IRAP MARKERS IN MASTIC TREE (Pistacia lentiscus L.) FROM TURKEY
}

\author{
Pelin TURHAN-SERTTAŞ*, Tamer ÖZCAN \\ İstanbul University, Faculty of Science, Department of Biology, İstanbul, TURKEY \\ ORCID ID: orcid.org/0000-0001-8617-7437 \\ *Corresponding author: e-mail: pelinturhansettas@gmail.com
}

Cite this article as:

Turhan-Serttaş P., Özcan T. 2018. Intraspecific Variations Studied by ISSR and IRAP Markers in Mastic Tree (Pistacia lentiscus L.) from Turkey. Trakya Univ J Nat Sci, 19(2): 147-157, DOI: 10.23902/trkjnat.433329

Received: 12 June 2018, Accepted: 20 September 2018, Online First: 03 October 2018, Published: 15 October 2018

\begin{abstract}
In this study, intra-specific variations in naturally growing and cultivated mastic tree (Pistacia lentiscus L.) samples obtained from western parts of Turkey were examined using ISSR and IRAP marker techniques. Samples from Crete and Chios were also included in the study. Morphological measurements of some leaf characteristics of the samples were performed and the measured data was evaluated statistically with a Pearson Correlation analysis to reveal the correlations between character pairs. ISSR primers produced 81 bands between $161-1884 \mathrm{bp}$ with $96.3 \%$ polymorphism and IRAP primers produced 72 bands between 124-2027bp with $91.67 \%$ polymorphism. Polymorphism information content (PIC) values were 0.458 and 0.418 for ISSR and IRAP, respectively. Genetic similarity matrix was examined with Jaccard's coefficient. Maximum similarity was found between the Cretan samples (LG2 and LG3) with the ISSR analysis (0.933) and between L25A (C1, Bodrum) and L29A (C1, Milas) with the IRAP analysis (0.593). Unweighted pair group method with arithmetic mean (UPGMA) dendrogram was divided into 12 and 4 groups by ISSR and IRAP methods, respectively. Specimens were segregated on 3 main different clusters by the Principal Component Analysis (PCA) based on the combined marker systems. The results showed that P. lentiscus has very high ratios of intraspecific variation. The present work is an original study in terms of large sampling including wild genotypes, cultivated specimen, Chios and Cretan varieties, use of ISSR and IRAP combination, determination of relations between culture and wild genotypes and the use of Bagy-1 retrotransposons in intraspecific polymorphism. This study may be considered as a reference study for studies on gene pools of $P$. lentiscus and phylogenetic relationships within the species and may contribute to species concept and agricultural breeding programs.
\end{abstract}

Key words: IRAP, ISSR, Phylogenetics analysis.

Özet: Bu çalışmada, ISSR ve IRAP markör teknikleri kullanılarak Türkiye'nin batı kesiminde doğal olarak yetişen ve kültürü yapılan sakız ağacı (Pistacia lentiscus L.) örneklerindeki tür içi varyasyon analizi yapılmıştır. Girit ve Sakız Adası örnekleri de çalışmaya dahil edilmiştir. Bazı yaprak özelliklerinin morfolojik ölçümleri gerçekleştirilmiş ve aralarındaki korelasyon Pearson Korelasyon analizi ile belirlenmiştir. ISSR primerleri 161-1884bç arasında \%96,3 polimorfizm ile 81 bant üretmiştir. IRAP primerleri ise 124-2027bç arasında \%91,67 polimorfizm ile 72 bant üretmiştir. Polimorfizm bilgi içeriği (PIC) değerleri 0,458 (ISSR) ve 0,418 (IRAP) arasında bulunmuştur. Genetik benzerlik matriksleri Jaccard katsayısıyla oluşturulmuştur. ISSR sonuçlarında en yüksek benzerlik Girit örnekleri (LG2 ve LG3) arasında $(0,933)$ ve IRAP sonuçlarında ise L25A (C1, Bodrum) ve L29A (C1, Milas) arasında bulunmuştur. UPGMA yöntemiyle kurulan dendrogramlarda sırasıyla ISSR için 12 grup ve IRAP için 4 grup ayrılmıştır. Her iki markör sistemi için ortak kurulan temel bileşen analizi (PCA) grafiğinde 3 farklı küme oluşmuştur. Sonuçlar göstermiştir ki, P. lentiscus yüksek oranlarda tür içi varyasyona sahiptir. Bu çalışma, ISSR ve IRAP markörlerinin yabani genotipler, kültür türleri, Sakız Adası ve Girit çeşitlerinin analizinde kullanımı, kültür varyeteleri ve yabani genotipler arasındaki ilişkilerin belirlenmesi ve tür içi polimorfizmde Bagy-1 retrotranspozonlarının kullanımı açısından özgün bir çalışmadır. Söz konusu çalışma, $P$. lentiscus gen havuzunun ve filogenetik ilişkilerinin araştırılması, tür sınırlarını saptamaya yönelik yapılacak tarımsal ıslah çalışmaları için referans niteliğindedir.

\section{Introduction}

The genus Pistacia L. within the family Anacardiaceae is represented with 11 species worldwide and with six naturally growing species in Turkey (Stevens 2008, Kafkas \& Perl-Treves 2001, Kokwaro \& Gillet 1980, Whitehouse 1957, Yaltırık 1967, Zohary 1952). Members of the genus grow naturally in various areas of the northern hemisphere including the Middle East, Canary Islands and the Mediterranean region (Ak \& Parlakçı 2009). Pistacia genus is believed to have originated in Central Asia 80 million years ago (ALSaghir 2010, Parfitt \& Badenes 1997). Mastic tree (lentisk) (Pistacia lentiscus L.) is an economically 
important species of the genus in terms of mastic resin which has a wide spectrum of biomedical usage and cultivated for its aromatic resin. As an evergreen dioecious maquis element with a height ranging from 1 to $5 \mathrm{~m}$ and a strong smell of resin, $P$. lentiscus bears fleshy drupe with an initial red colour which becomes black after ripening. The leaves are compound paripinnate, alternate, and leathery. The high ecological tolerance of the species allows it to resists heavy frosts and drought (Correia \& Catarino 1994) and to grow well in all types of soils ranging from limestone areas to saline environments around sea (Zohary 1952). Its resin, known as mastic, is harvested as a spice from cultivated mastic trees and used in food industry, cosmetics and medicine with therapeutic effects such as gastrointestinal ailments, and antibacterial and antifungal properties. Mastic resin is reported to be effective in inhibition of cell lines of some cancer types including colon (Balan et al. 2007), prostate (He et al. 2007), and erytrolosemi (Loutrari et al. 2006). Analysing gene pools and conservation of genetic resources of $P$. lentiscus are important strategies for selection of high yield genotypes adapted to various environmental conditions and for increasing product potential in breeding programmes. Pistacia has formerly been divided into four groups as Lenticella, Eu-Lentiscus, Butmela and Eu-terebinthus including 11 species in total based on some morphological observations of Zohary (1952) and Whitehouse (1957). In the first molecular study based on chloroplast DNA, two groups, Terebinthus and Lentiscus, represented by deciduous and evergreen plants were suggested to be placed in Pistacia (Parfitt \& Badenes 1997). The group Terebinthus was also supported by some molecular studies carried on Mediterranean Pistacia species (Golan-Goldrish et al. 2004, Kafkas and PerlTreves 2001, Kafkas \& Perl-Treves 2002, Kafkas 2006). Some morphological characters such as features of rachis and compound leaves, shape, colors and venation of the leaflets, shape of fruits are used in taxonomical delimitations of Pistacia species in Turkey (Yaltırık 1967). Some studies were performed on Turkish Pistacia species based on random amplified polymorphic DNA (RAPD) (Kafkas \& Perl-Treves 2002) and amplified fragment length polymorphism (AFLP) markers (Kafkas 2006) explaining some taxonomical relations of the species and suggesting some nomenclatural combinations. In a recent work carried on $P$. Lenticus in Turkey, Inter Simple Sequence Repeat (ISSR), Simple Sequence Repeat (SSR), RAPD and Internal Transcribed Spacer (ITS) markers were used to evaluate patterns of genetic variation and phylogenetic relationships in 24 wild-type mastic trees (Abuduli et al. 2016). The ISSR results indicated that male and female genotypes were distinctly separated from each other and that ISSR markers were useful for analysis of intraspecific variations in mastic trees.

ISSRs are defined as inter-gene regions of microsatellites and ISSR markers are used as molecular markers in polymorphism studies. Microsatellites occuring at thousands of locations within a genome are widely used for DNA profiling, genetic diversity, genetic linkage analysis and marker assisted selection (MAS) to locate a gene or a mutation responsible for a given trait. They are also used, owing to their high polymorphism rates, in phylogeographic studies (Nagy et al. 2003) and to measure the levels of relatedness between infraspecific taxa, groups and individuals (Fritz et al. 2005). As an alternative valuable retrotransposon-based marker, interretrotransposon amplified polymorphism (IRAP) markers are also used to determine genotypes, measure diversity, establish taxonomical relations or reconstruct phylogeny (Kalendar et al. 1999). Retrotransposons which are mobile genetic elements can induce mutations by inserting near or within genes. The copy number of retrotransposons exhibit diagnostic patterns among closely related plant taxa (Tenaillon et al. 2011) and are useful for determining genetic diversity within a species (Kolano et al. 2013) in addition to genomic changes associated with retrotransposon activity in abiotic stress conditions (Fan et al. 2014). Retrotransposons are divided into two groups according to the presence or absence of long terminal repeats (LTR). The LTR retrotransposons were well analyzed at different taxonomical categories of plants (Park et al. 2007, Ma et al. 2008).

In this study, intra-specific variations in 35 samples of naturally growing and culture varieties of $P$. lentiscus obtained from various localities in Turkey, Chios and Crete were examined using ISSR and IRAP marker techniques in order to provide data for elucidating the gene pool of the species in the sampling region, contribute its revision, taxonomical delimitation and its phylogeographical relations. For phylogenetic analysis, dendrograms were generated based on ISSR and IRAP data and the marker results were evaluated by PCA analysis. Morphological measurements of the collected specimens were also carried out to determine similarity coefficients of phenotypic characters at population level.

\section{Materials and Methods}

\section{$\underline{\text { Plant material }}$}

Pistacia lentiscus specimens were collected from 31 native populations distributed in İstanbul (A2(E)), İzmir (B1), Muğla and Aydın (C1 and C2) according to the grid system of Turkey. Four specimens collected from Chios (1) and Cretan (3) were also included in the study (Table 1). The collected specimens were prepared as herbarium materials and are kept in ISTF (Herbarium of İstanbul University Faculty of Sciences). Leaf samples of the collected specimens were transported to the laboratory in polypropylene bags and kept at $-80^{\circ} \mathrm{C}$ conditions until the analysis.

\section{Morphological analysis}

The lengths of leaflet tips, widths and lengths of rachis, leaf and leaflets were measured and leaflet numbers and the shapes of leaflets were determined using binocular stereomicroscope. Each measurement was performed as five replicates for each character. A variance 
analysis (ANOVA) was performed with the obtained data to determine phenotypically differences. The Pearson correlation test was performed to determine the relationships between measured characters.

\section{$\underline{\text { DNA isolations }}$}

Genomic DNA isolations of P. lentiscus specimens were performed by the CTAB method of Lodhi et al. (1994) with minor modifications. The concentration and purity of the genomic DNA samples were evaluated in the Nanodrop 2000c instrument. Qualities of the genomic DNAs were analyzed by running on $0.8 \%$ agarose gel using 1xTBE buffer and ethidium bromide (EtBr). Scanning of the gels was carried out under UV (GELIANCE 200 Imaging System with GeneSnap software).

\section{PCR Amplification of ISSR and IRAP}

Polymerase chain reaction (PCR) amplifications of the DNA samples were carried out in Thermo Scientific Arktik Thermal Cycler using 12 ISSR and 14 IRAP primers (Table 2). The primers showing clear bands on gel images were selected. The ISSR amplifications were analyzed in volumes of $20 \mu \mathrm{l}$ including $1 \times \mathrm{xPR}$ buffer, 2.5 $\mathrm{mM} \mathrm{MgCl}_{2}, 0.4 \mathrm{mM}$ dNTP mix (dATTP, dGTP, dCTP and dTTP), 1U Taq DNA polymerase, $0.4 \mathrm{mM}$ for each ISSR primer, 50ng DNA sample and DNase/RNase free water. The PCR reactions for ISSR markers were programmed with the following conditions: after initial denaturation of DNA at $95^{\circ} \mathrm{C}$ for $5 \mathrm{~min}, 35$ cycles of denaturation at $95^{\circ} \mathrm{C}$ for $30 \mathrm{sec}$, annealing $\left(\mathrm{T}_{\mathrm{a}}{ }^{\circ} \mathrm{C}\right.$ is different for each primer) (Table 2) for $1 \mathrm{~min}, 72^{\circ} \mathrm{C}$ for $1 \mathrm{~min}$ and final extension at $72^{\circ} \mathrm{C}$ for $5 \mathrm{~min}$. The IRAP

Table 1. The details of the localities of Pistacia lentiscus L. specimens included in the study.

\begin{tabular}{|c|c|c|c|c|c|c|c|c|c|}
\hline No & Accessions & Grid no & Altitude & Coordinates & No & Accessions & Grid no & Altitude & Coordinates \\
\hline 1 & L2A & $\mathrm{C} 1$ & $19 \mathrm{~m}$ & $\begin{array}{l}37^{\circ} 41 ' 46.333^{\prime \prime N} \\
27^{\circ} 41^{\prime} 44.622^{\prime \prime} \mathrm{E}\end{array}$ & 19 & L23A & $\mathrm{C} 1$ & $16 \mathrm{~m}$ & $\begin{array}{l}37^{\circ} 01^{\prime} 45.05^{\prime \prime} \mathrm{N} \\
27^{\circ} 25^{\prime} 02.05^{\prime} \mathrm{E}\end{array}$ \\
\hline 2 & L2B & $\mathrm{C} 1$ & $19 \mathrm{~m}$ & $\begin{array}{l}37^{\circ} 41 ' 46.333^{\prime \prime} \mathrm{N} \\
27^{\circ} 41^{\prime} 44.62^{\prime \prime} \mathrm{E}\end{array}$ & 20 & L24A & $\mathrm{C} 1$ & $3 \mathrm{~m}$ & $\begin{array}{l}37^{\circ} 08^{\prime} 11.80^{\prime \prime} \mathrm{N} \\
27^{\circ} 34^{\prime} 51.94^{\prime \prime} \mathrm{E}\end{array}$ \\
\hline 3 & L11A & $\mathrm{C} 1$ & $118 \mathrm{~m}$ & $\begin{array}{l}37^{\circ} 27^{\prime} 39.68^{\prime \prime} \mathrm{N} \\
27^{\circ} 22^{\prime} 38.99 ’ \mathrm{E}\end{array}$ & 21 & L25A & $\mathrm{C} 1$ & $3 \mathrm{~m}$ & $\begin{array}{l}37^{\circ} 08^{\prime} 11.80^{\prime \prime} \mathrm{N} \\
27^{\circ} 34^{\prime} 51.94^{\prime \prime} \mathrm{E}\end{array}$ \\
\hline 4 & L11B & $\mathrm{C} 1$ & $118 \mathrm{~m}$ & $\begin{array}{l}37^{\circ} 27^{\prime} 39.68^{\prime \prime} \mathrm{N} \\
27^{\circ} 22^{\prime} 38.999^{\prime \prime}\end{array}$ & 22 & L26A & $\mathrm{C} 1$ & $3 \mathrm{~m}$ & $\begin{array}{l}37^{\circ} 08^{\prime} 11.80^{\prime \prime} \mathrm{N} \\
27^{\circ} 34^{\prime} 51.94^{\prime \prime} \mathrm{E}\end{array}$ \\
\hline 5 & L16A & $\mathrm{C} 1$ & $172 \mathrm{~m}$ & $\begin{array}{l}37^{\circ} 19^{\prime} 44.744^{\prime \prime} \mathrm{N} \\
27^{\circ} 39^{\prime} 07.03 \text { 'E }\end{array}$ & 23 & L30A & $\mathrm{C} 1$ & $141 \mathrm{~m}$ & $\begin{array}{l}37^{\circ} 43^{\prime} 51.711^{\prime \prime} \mathrm{N} \\
27^{\circ} 23 \text { '18.03'E }\end{array}$ \\
\hline 6 & L16B & $\mathrm{C} 1$ & $172 \mathrm{~m}$ & $\begin{array}{l}37^{\circ} 19^{\prime} 44.744^{\prime \prime} \mathrm{N} \\
27^{\circ} 39^{\prime} 07.033^{\prime} \mathrm{E}\end{array}$ & 24 & L33A & $\mathrm{C} 2$ & $62 \mathrm{~m}$ & $\begin{array}{l}36^{\circ} 45^{\prime} 39.44^{\prime \prime} \mathrm{N} \\
28^{\circ} 56^{\prime} 04.64{ }^{\prime \prime} \mathrm{E}\end{array}$ \\
\hline 7 & L16C & $\mathrm{C} 1$ & $172 \mathrm{~m}$ & $\begin{array}{l}37^{\circ} 19^{\prime} 44.74^{\prime \prime} \mathrm{N} \\
27^{\circ} 39^{\prime} 07.03 \text { 'E }\end{array}$ & 25 & L33B & $\mathrm{C} 2$ & $62 \mathrm{~m}$ & $\begin{array}{l}36^{\circ} 45^{\prime} 39.44^{\prime \prime} \mathrm{N} \\
28^{\circ} 56^{\prime} 04.64 \text { 'E }\end{array}$ \\
\hline 8 & L17A & $\mathrm{C} 1$ & $0 \mathrm{~m}$ & $\begin{array}{l}37^{\circ} 16^{\prime} 55.88^{\prime \prime} \mathrm{N} \\
27^{\circ} 35^{\prime} 21.58^{\prime \prime} \mathrm{E}\end{array}$ & 26 & L34A & $\mathrm{C} 2$ & $62 \mathrm{~m}$ & $\begin{array}{l}36^{\circ} 45^{\prime} 39.44^{\prime \prime} \mathrm{N} \\
28^{\circ} 56^{\prime} 04.64^{\prime \prime} \mathrm{E}\end{array}$ \\
\hline 9 & L17B & $\mathrm{C} 1$ & $0 \mathrm{~m}$ & $\begin{array}{l}37^{\circ} 16^{\prime} 55.88^{\prime \prime} \mathrm{N} \\
27^{\circ} 35^{\prime} 21.58^{\prime \prime} \mathrm{E}\end{array}$ & 27 & LEU & B1 & $50 \mathrm{~m}$ & $\begin{array}{l}38^{\circ} 45^{\prime} 58.633^{\prime \prime} \mathrm{N} \\
27^{\circ} 22^{\prime} 89.37^{\prime \prime} \mathrm{E}\end{array}$ \\
\hline 10 & L17C & $\mathrm{C} 1$ & $0 \mathrm{~m}$ & $\begin{array}{l}37^{\circ} 16^{\prime} 55.88^{\prime \prime} \mathrm{N} \\
27^{\circ} 35^{\prime} 21.58^{\prime \prime} \mathrm{E}\end{array}$ & 28 & LCHIA & - & - & $\begin{array}{l}38^{\circ} 37^{\prime} 24.71^{\prime \prime} \mathrm{N} \\
25^{\circ} 92^{\prime} 42.12^{\prime \prime} \mathrm{E}\end{array}$ \\
\hline 11 & L18A & $\mathrm{C} 1$ & $0 \mathrm{~m}$ & $\begin{array}{l}37^{\circ} 16^{\prime} 55.88^{\prime \prime} \mathrm{N} \\
27^{\circ} 35^{\prime} 21.58^{\prime \prime} \mathrm{E}\end{array}$ & 29 & LCES1 & B1 & $10 \mathrm{~m}$ & $\begin{array}{l}38^{\circ} 32^{\prime} 35.56^{\prime \prime} \mathrm{N} \\
26^{\circ} 28^{\prime} 31.48^{\prime \prime} \mathrm{E}\end{array}$ \\
\hline 12 & L19A & $\mathrm{C} 1$ & $43 \mathrm{~m}$ & $\begin{array}{l}37^{\circ} 17^{\prime} 01.10^{\prime \prime} \mathrm{N} \\
27^{\circ} 34^{\prime} 32.55^{\prime \prime} \mathrm{E}\end{array}$ & 30 & LCES2 & B1 & $10 \mathrm{~m}$ & $\begin{array}{l}38^{\circ} 32^{\prime} 35.56^{\prime \prime} \mathrm{N} \\
26^{\circ} 28^{\prime} 31.48^{\prime \prime} \mathrm{E}\end{array}$ \\
\hline 13 & L28A & $\mathrm{C} 1$ & $8 \mathrm{~m}$ & $\begin{array}{l}37^{\circ} 15^{\prime} 32.72^{\prime \prime} \mathrm{N} \\
27^{\circ} 311^{\prime} 28.48^{\prime \prime} \mathrm{E}\end{array}$ & 31 & LG1 & - & $200 \mathrm{~m}$ & $\begin{array}{l}35^{\circ} 10^{\prime} 11.00^{\prime \prime} \mathrm{N} \\
24^{\circ} 58^{\prime} 38.8^{\prime} \mathrm{E}\end{array}$ \\
\hline 14 & L28B & $\mathrm{C} 1$ & $8 m$ & $\begin{array}{l}37^{\circ} 15^{\prime} 32.72^{\prime \prime} \mathrm{N} \\
27^{\circ} 31^{\prime} 28.48^{\prime \prime} \mathrm{E}\end{array}$ & 32 & LG2 & - & $200 \mathrm{~m}$ & $\begin{array}{l}35^{\circ} 10^{\prime} 11.0^{\prime \prime} \mathrm{N} \\
24^{\circ} 58^{\prime} 38.8^{\prime \prime} \mathrm{E}\end{array}$ \\
\hline 15 & L29A & $\mathrm{C} 1$ & $8 \mathrm{~m}$ & $\begin{array}{l}37^{\circ} 15^{\prime} 32.72^{\prime \prime} \mathrm{N} \\
27^{\circ} 31^{\prime} 28.48^{\prime \prime} \mathrm{E}\end{array}$ & 33 & LG3 & - & $200 \mathrm{~m}$ & $\begin{array}{l}35^{\circ} 10^{\prime} 11.0^{\prime \prime} \mathrm{N} \\
24^{\circ} 58^{\prime} 38.8^{\prime \prime} \mathrm{E}\end{array}$ \\
\hline 16 & L21B & $\mathrm{C} 1$ & $16 \mathrm{~m}$ & $\begin{array}{l}37^{\circ} 01^{\prime} 45.05^{\prime \prime} \mathrm{N} \\
27^{\circ} 25^{\prime} 02.05^{\prime} \mathrm{E}\end{array}$ & 34 & LZB & $\mathrm{A} 2(\mathrm{E})$ & $10 \mathrm{~m}$ & $\begin{array}{l}40^{\circ} 58^{\prime} 00.59^{\prime \prime} \mathrm{N} \\
28^{\circ} 53^{\prime} 00.59^{\prime \prime} \mathrm{E}\end{array}$ \\
\hline 17 & L22A & $\mathrm{C} 1$ & $16 \mathrm{~m}$ & $\begin{array}{l}37^{\circ} 011^{\prime} 45.05^{\prime \prime} \mathrm{N} \\
27^{\circ} 25^{\prime} 02.05^{\prime \prime} \mathrm{E}\end{array}$ & 35 & LBB & $\mathrm{A} 2(\mathrm{E})$ & $69 \mathrm{~m}$ & $\begin{array}{l}41^{\circ} 0{ }^{\prime} 43.56 ” \mathrm{~N} \\
8^{\circ} 57^{\prime} 50.21^{\prime \prime} \mathrm{E}\end{array}$ \\
\hline 18 & L22B & $\mathrm{C} 1$ & $16 \mathrm{~m}$ & $\begin{array}{l}37^{\circ} 01^{\prime} 45.05^{\prime \prime} \mathrm{N} \\
27^{\circ} 25^{\prime} 02.05^{\prime \prime} \mathrm{E}\end{array}$ & & & & & \\
\hline
\end{tabular}


Table 2. The list of the ISSR and IRAP primers with their corresponding $\mathrm{Ta}^{\circ} \mathrm{C}$ values and 5' -3 ' sequences.

\begin{tabular}{|c|c|c|c|c|}
\hline No & $\begin{array}{l}\text { Primer } \\
\text { code }\end{array}$ & References & Sequences (5'-3') & $\begin{array}{c}\text { Annealing } \\
\text { temperature } \\
\left(\mathrm{Ta}^{\circ} \mathrm{C}\right) \\
\end{array}$ \\
\hline 1 & ISSR1 & UBC-864 & ATG ATG ATG ATG ATG ATG & 49.8 \\
\hline 2 & ISSR2 & UBC-828 & TGT GTG TGT GTG TGT GA & 45.7 \\
\hline 3 & ISSR3 & UBC-815 & СТС ТСТ СТС ТСТ СТС TG & 56.2 \\
\hline 4 & ISSR4 & UBC-827 & ACA CAC ACA CAC ACA CG & 56.2 \\
\hline 5 & ISSR5 & UBC-823 & ТCT СТC ТСТ СТС ТСТ СC & 51.0 \\
\hline 6 & ISSR6 & RAMP-TAG & TAG AGA GAG AGA GAG AGA G & 59.0 \\
\hline 7 & ISSR7 & UBC-807 & AGA GAG AGA GAG AGA GT & 52.2 \\
\hline 8 & ISSR8 & UBC-813 & СТC ТСТ СТC ТСТ СТC ТT & 50.4 \\
\hline 9 & ISSR9 & UBC-861 & ACC ACC ACC ACC ACC ACC & 57.6 \\
\hline 10 & ISSR10 & UBC-862 & AGC AGC AGC AGC AGC AGC & 64.7 \\
\hline 11 & ISSR11 & UBC-844A & СТС ТСТ СТС ТСТ СТС ТАС & 53.7 \\
\hline 12 & ISSR12 & 17899A & CAC ACA CAC ACA CAC AG & 43.4 \\
\hline 13 & IRAP1 & 560LTR, Wis2 & TTGCCTCTAGGGCATATTTCCAACA & 60.0 \\
\hline 14 & IRAP2 & 2107LTR, Wilma & AGCATGATGCAAAATGGACGTATCA & 60.0 \\
\hline 15 & IRAP3 & 2109LTR, Daniela & TAC CCC TAC TTT AGT ACA CCG ACA & 60.0 \\
\hline 16 & IRAP4 & 2114LTR, Fatima & GGACACCCCCTAATCCAGGACTCC & 60.0 \\
\hline 17 & IRAP5 & 728LTR, Sabrina & TGTCACGTCCAAGATGCGACTCTATC & 60.0 \\
\hline 18 & IRAP6 & 432LTR, Sukkula & GATAGGGTCGCATCTTGGGCGTGAC & 60.0 \\
\hline 19 & IRAP7 & LTR SukkulaLARD & TAGGGTCGCATCTTGGGCGTGACA & 60.0 \\
\hline 20 & IRAP8 & 2123LTR, Wham & GGAAAAGTAGATACGACGGAGACGT & 60.0 \\
\hline 21 & IRAP9 & 552LTR, Bagyl & CGATGTGTTACAGGCTGGATTCC & 60.0 \\
\hline 22 & IRAP10 & 1369LTR, BARE1 & TGCCTCTAGGGCATATTTCCAACAC & 60.0 \\
\hline 23 & IRAP11 & LTR6149, BARE-1 & CTCGCTCGCCCACTACATCAACCGCGTTTATT & 60.0 \\
\hline 24 & IRAP12 & LTR4, $1111 \leftarrow 1133$ & AGCCTGAAAGTGTTGGGTTGTCG & 59.0 \\
\hline 25 & IRAP13 & LTR7, $460 \rightarrow 486$ & CACTTCAAATTTTGGCAGCAGCGGATC & 60.0 \\
\hline 26 & IRAP14 & LTR $2,8 \leftarrow 30$ & CTTGCTGGAAAGTGTGTGAGAGG & 55.0 \\
\hline
\end{tabular}

reactions were performed in $25 \mu \mathrm{l}$ volumes containing 1xPCR tampon, 2.5mM MgCl $2,0.4 \mathrm{mM}$ dNTP mix, $2 \mathrm{U}$ Taq DNA polymerase, $1 \mu \mathrm{M}$ primer, 50ng DNA sample and water using the protocol of Kalendar et al. (2011) with minor modifications: initial denaturation at $95^{\circ} \mathrm{C}$ for $3 \mathrm{~min}$, 35 cycles of denaturation at $95^{\circ} \mathrm{C}$ for $1 \mathrm{~min}$, annealing $\left(\mathrm{T}_{\mathrm{a}}{ }^{\circ} \mathrm{C}\right.$ is different for each primers) (Table 2) for $45 \mathrm{sec}, 68^{\circ} \mathrm{C}$ for $3 \mathrm{~min}$ and final extension at $72^{\circ} \mathrm{C}$ for $5 \mathrm{~min}$. The PCR products stained with the loading dye were analyzed by running on a $1.5 \%$ agarose gel with using $1 \mathrm{xTBE}$ and EtBr. Visualisation of the gels with fragmented DNA was carried out under UV (GELIANCE 200 Imaging System with GeneSnap software).

\section{Evaluation of the datasets}

The "Thermo Scientific myImage Analysis v2.0" software was used to determine the band molecular sizes using the gel images. The band fragments were visually scored for presence (1) or absence (0) on their gel patterns (additional data are given at the journal's web page as Supplemantary Material Table 6). The polymorphism information content (PIC) value was calculated according to the formula;

$$
\mathrm{PIC}=2 \mathrm{P} i(1-\mathrm{P} i)
$$

where $\mathrm{P} i$ represents the frequency of polymorphic bands present for a primer (Bhat 2002). The similarity coefficient matrix of the analyses was made based on the "Jaccard" similarity formula (Jaccard 1908) and was generated with the PASW18 software. The results were evaluated by constructing dendrograms for ISSR and IRAP according to the Jaccard's similarity coefficients. In order to determine phylogenetic relationships, unweighted pair group method with arithmetic mean (UPGMA) algorithm was produced using the XLSTAT package program. The distribution of the genotypes in the $P$. lentiscus gene pool was assessed by the principle component analysis (PCA) based on ISSR and IRAP data. The PCA analyses were also performed using the XLSTAT package program.

\section{Results}

\section{Morphological analysis}

The results of the morphological measurements (see Table 3) showed that the minimum and maximum values were $0.31 \mathrm{~mm}$ and $1.42 \mathrm{~mm}$ for the tip length of leaflets. The minimum rachis length was measured as $1.93 \mathrm{~cm}$ for $\mathrm{L} 28 \mathrm{~A}$ and the maximum as $5.71 \mathrm{~cm}$ for $\mathrm{LZB}$ and the rachis width ranged from $1.10 \mathrm{~mm}$ (L16B) to $2.69 \mathrm{~mm}$ (L11A). The lowest leaf size was measured as $3.66 \mathrm{~cm}$ for L28A and the highest value as $7.68 \mathrm{~cm}$ for LZB. The average value of the leaflet lenght in the population was calculated as $2.73 \mathrm{~cm}$ (Table 3 ). The results of the Pearson correlation analysis were given in Table 4. A high correlation level $(\mathrm{p}<0.01)$ was determined between the pairs of the morphological characters, and the highest correlation $(r=0.901)$ was measured between leaf width and leaflet size.

\section{ISSR and IRAP polymorphism analysis}

Although a total of 12 different primers were used for ISSR analysis, 9 of them were included in the band analysis. A total of 81 bands and 1444 amplicons were 
obtained between $161 \mathrm{bp}$ and 1884 bp per ISSR primer and 3 of them were monomorphic band (Fig. 1). The lowest and the highest PIC values were 0.368 and 0.495 , respectively. The mean PIC value was 0.458 and the polymorphism rate was found to be $96.3 \%$ (Table 5).

14 different primers were tested in the IRAP-PCR. Bagy1, BARE-1 and Sukkula LTR-retrotransposon primers were determined after the PCRs. Bagy-1 retrotransposon primer (IRAP9), LTR4 primer (IRAP12) and LTR2 primer (IRAP14) were selected based on the clearly produced band profiles in agarose gel electrophoresis, and the other primers were not included in the assays since they were determined to be monomorphic.

Table 3. The average values of each morphological measurement and the leaflet shape details of the specimens. a; oblanceolate, b; oblong-obovate, c; oblanceolate-obovate, d; ovate-oblanceolate, e; oblong-oblanceolate, f; orbicular-oblanceolate, g; ovaet, h; ovalobovate.

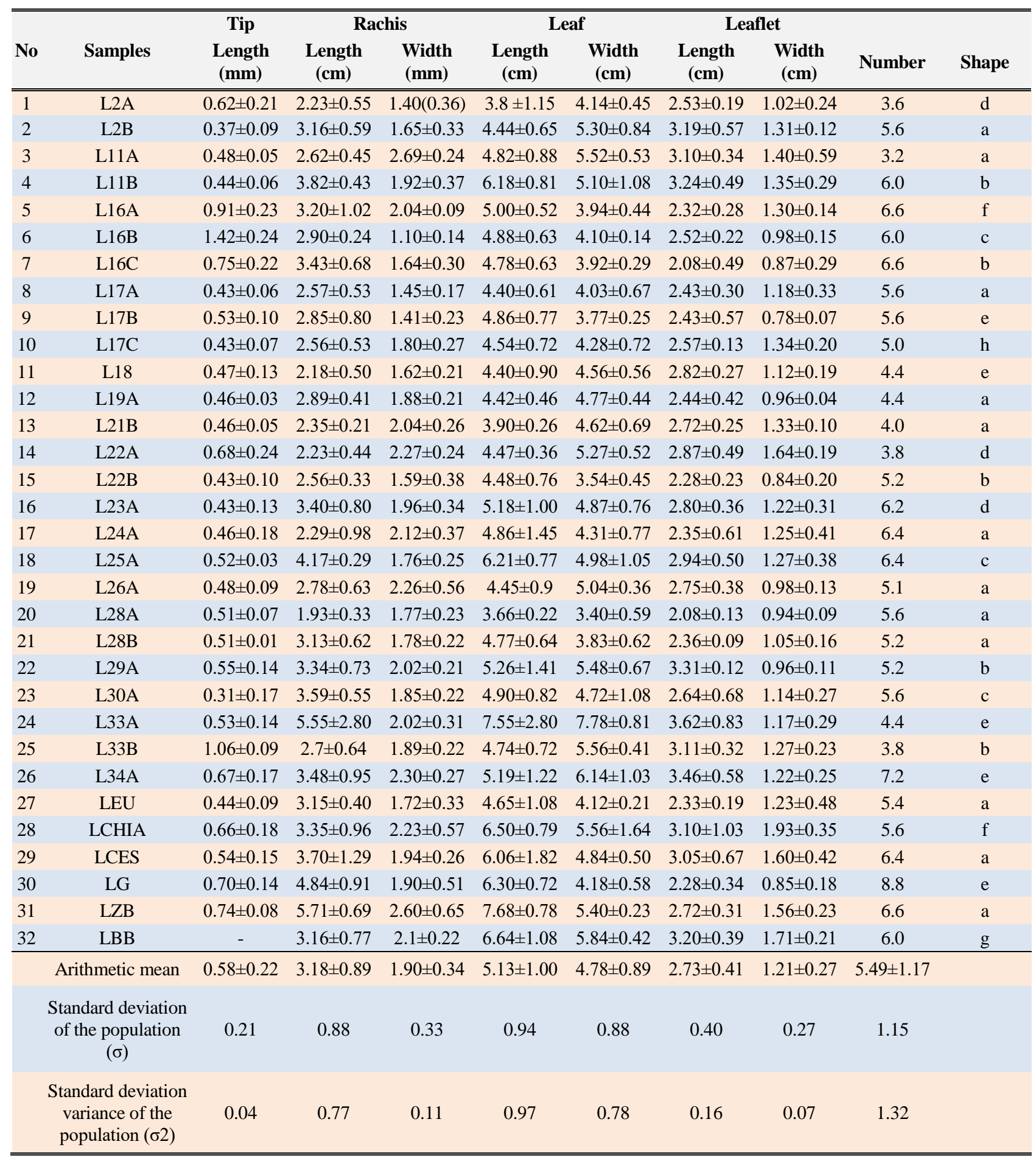


Table 4. The correlation values between the character pairs.

\begin{tabular}{|c|c|c|c|c|c|c|c|c|c|}
\hline & & \multirow{2}{*}{$\begin{array}{c}\text { Tip } \\
\text { L }\end{array}$} & \multicolumn{2}{|c|}{ Rachis } & \multicolumn{2}{|c|}{ Leaf } & \multicolumn{3}{|c|}{ Leaflet } \\
\hline & & & $\mathbf{L}$ & $\mathbf{W}$ & $\mathbf{L}$ & $\mathbf{W}$ & $\mathbf{L}$ & W & $\mathbf{N}$ \\
\hline Tip & $\mathbf{L}$ & - & 0.082 & -0.158 & 0.126 & -0.007 & -0.046 & -0.003 & 0.141 \\
\hline \multirow[b]{2}{*}{ Rachis } & $\mathbf{L}$ & 0.082 & - & 0.286 & $0.877^{* *}$ & $0.497^{* *}$ & 0.331 & 0.130 & $0.493^{* * *}$ \\
\hline & $\mathbf{W}$ & -0.158 & 0.286 & - & $0.397^{*}$ & $0.552^{* *}$ & $0.426^{*}$ & $0.554^{* *}$ & -0.033 \\
\hline \multirow[b]{2}{*}{ Leaf } & $\mathbf{L}$ & 0.126 & $0.877^{* *}$ & $0.397^{*}$ & - & $0.600^{* * *}$ & $0.484^{* *}$ & $0.431^{*}$ & $0.423^{*}$ \\
\hline & $\mathbf{W}$ & -0.007 & $0.497^{* *}$ & $0.552^{* *}$ & $0.600^{* *}$ & - & $0.901^{* *}$ & $0.471^{* *}$ & -0.173 \\
\hline Leaflet & $\begin{array}{l}\mathbf{L} \\
\mathbf{W} \\
\mathbf{N} \\
\end{array}$ & $\begin{array}{l}-0.046 \\
-0.003 \\
0.141 \\
\end{array}$ & $\begin{array}{c}0.331 \\
0.130 \\
0.493^{* *} \\
\end{array}$ & $\begin{array}{c}0.426^{*} \\
0.554^{* *} \\
-0.033 \\
\end{array}$ & $\begin{array}{c}0.484^{* *} \\
0.431^{*} \\
0.423^{*}\end{array}$ & $\begin{array}{l}0.901^{* *} \\
0.471^{* *} \\
-0.173\end{array}$ & $\begin{array}{c}- \\
0.500^{* *} \\
-0.190\end{array}$ & $\begin{array}{c}0.500^{* *} \\
- \\
-0.083\end{array}$ & $\begin{array}{c}-0.190 \\
-0.083 \\
- \\
\end{array}$ \\
\hline
\end{tabular}

L (length), W (width), N (number). *Level of significance of correlation, 0,05. **Level of significance of correlation, 0,01.

Table 5. ISSR and IRAP analysis reaults for each primer.

\begin{tabular}{rlccccc}
\hline \hline Primer & $\begin{array}{c}\text { Range size } \\
(\mathbf{b p})\end{array}$ & $\begin{array}{c}\text { Total no of } \\
\text { amplicons }\end{array}$ & $\begin{array}{c}\text { Total no of } \\
\text { bands }\end{array}$ & $\begin{array}{c}\text { \% of } \\
\text { polymorphism }\end{array}$ & PIC \\
\hline \hline 1. & ISSR1 & $446-1071$ & 215 & 10 & 90.00 & 0.474 \\
2. & ISSR2 & $470-1197$ & 137 & 11 & 72.73 & 0.458 \\
3. & ISSR3 & $1008-1676$ & 35 & 4 & 50.00 & 0.375 \\
4. & ISSR4 & $564-1884$ & 120 & 9 & 66.67 & 0.470 \\
5. & ISSR5 & $369-1880$ & 187 & 9 & 66.67 & 0.486 \\
6. & ISSR6 & $271-1333$ & 228 & 13 & 92.31 & 0.499 \\
7. & ISSR7 & $282-1689$ & 201 & 10 & 70.00 & 0.494 \\
8. & ISSR9 & $287-533$ & 111 & 7 & 71.43 & 0.495 \\
9. & ISSR10 & $161-593$ & 212 & 8 & - & - \\
TOTAL & & - & 1444 & 81 & 96.30 & 0.458 \\
MEAN & & - & - & - & 85.00 & 0.398 \\
10. & IRAP9 & $164-1426$ & 192 & 20 & 94.29 & 0.384 \\
11. IRAP12 & $124-2027$ & 319 & 35 & 94.12 & 0.471 \\
12. & IRAP14 & $217-1844$ & 226 & 17 & - & - \\
TOTAL & - & 737 & 72 & 91.67 & 0.418 \\
MEAN & - & - & - & & \\
\hline \hline
\end{tabular}

The band results of the IRAP-PCR revealed a total of 737 amplicons from 72 band fragments between 124 bp and 2027 bp (Fig. 2). The mean PIC value for IRAP marker assay was found to be 0.418 (Table 5).

\section{$\underline{\text { Genetic similarity analysis }}$}

The percentages of similarity obtained as a result of whole ISSR and IRAP analyses were calculated with Jaccard's coefficient. According to ISSR datasets (additional data are given at the journal's web page as Supplemantary Material Table 7), similarity ratios varied between 0.080 and 0.933 . The lowest similarity was found to be $8 \%$ between LBB and L33A, and the highest (93\%) was between LG2 and LG3. The lowest polymorphism was found in LBB genotype with an average value of 0.127 and the highest polymorphism was in L28B genotype with an average value of 0.628 . The average values of the highest and lowest polymorphism values were calculated as 0.712 and 0.125, respectively. According to IRAP datasets (additional data are given at the journal's web page as Supplemantary Material Table 8), similarity ratios were found to between 0.087 and 0.593 . The lowest $(0.087)$ and highest (0.593) similarities were found between L11A and L33A, and between L25A and L29A, respectively. The minumum polymorphism was determined in L33A genotype with an average value of 0.2222 and the maximum polymorphism in L25A genotype with an average value of 0.404 . The average value of genetic similarity according to IRAP markers in all specimens was calculated as 0.323 . 

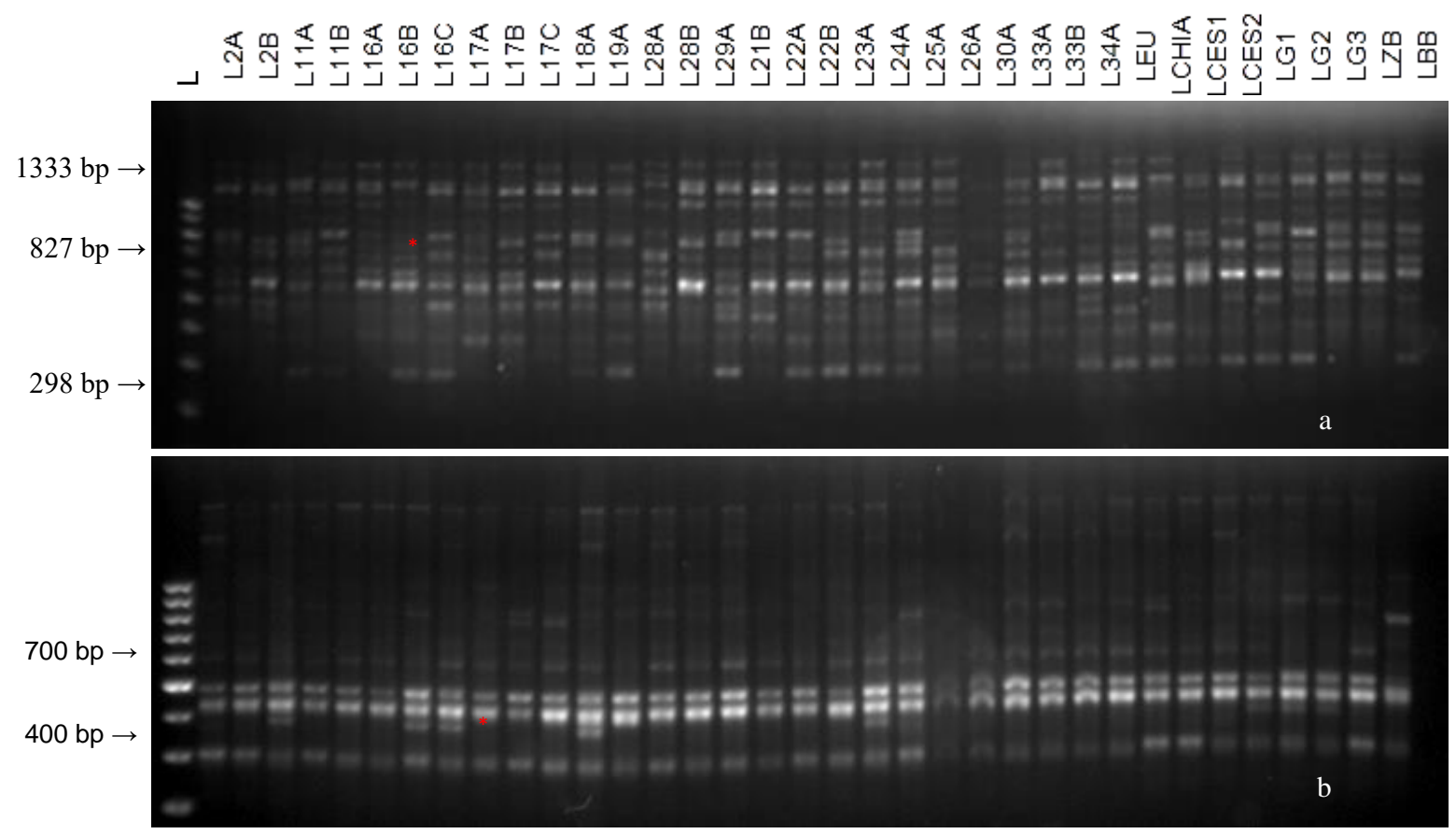

Fig. 1. Agarose gel electrophoresis of ISSR6 (a) and ISSR7 (b) L; 100bp DNA Ladder, red solid circle; polymorphic bands.

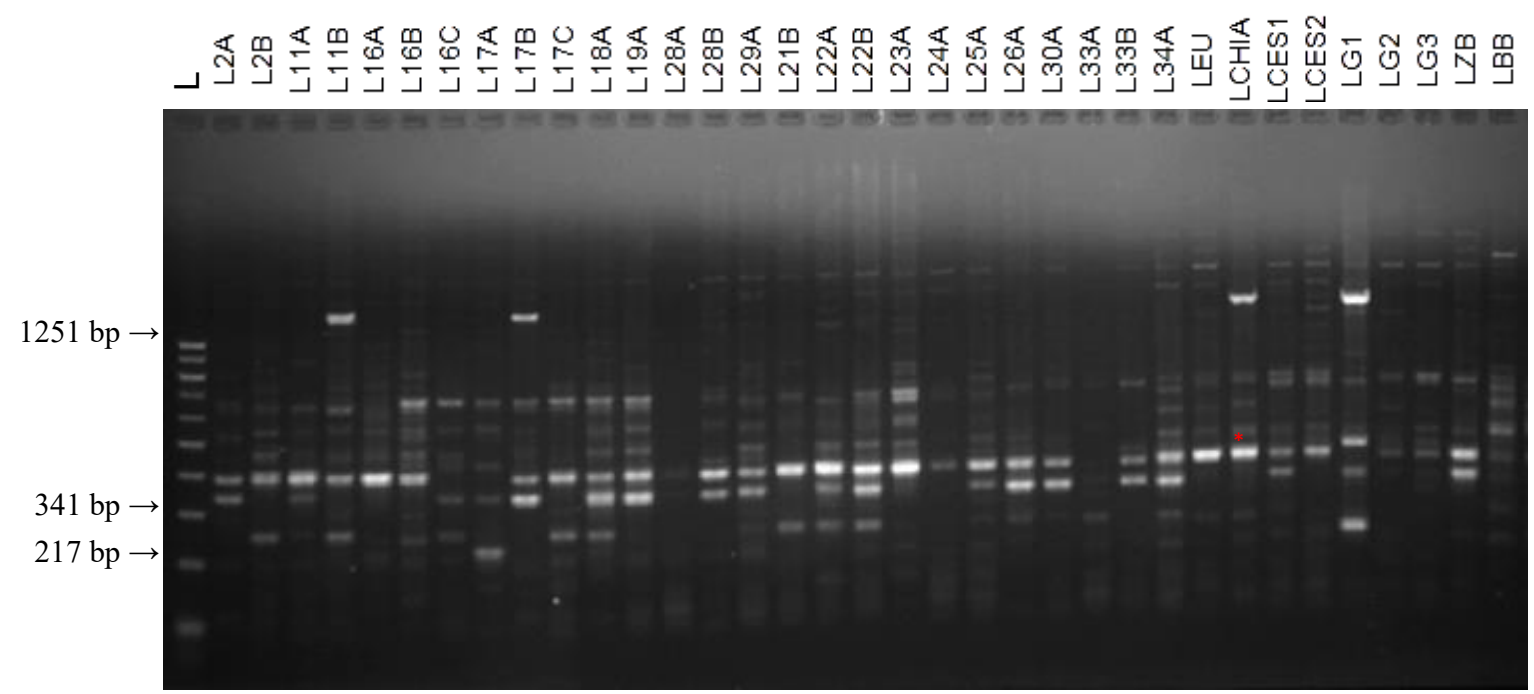

Fig. 2. Agarose gel electrophoresis of IRAP14. Red solid circle; polymorphic band.

\section{Phylogenetic analysis}

For phylogenetic analysis of the 35 P. lentiscus samples, phylogenetic trees were constructed by UPGMA method according to the data obtained from ISSR and IRAP. Dendrograms were constructed based on the Jaccard's similarity coefficient. The ISSR dendrogram was characterized with 12 different groups (Fig. 3). The first group (G1) consisted of L2A and L2B genotypes and the intra-group variance value was found to be 5.000. The second group (G2) included L11A, L16A, L17A, L17B, L17C and L33B genotypes and the group variance value was detected to be 8.867 . The third group (G3) was only represented by the L11B genotype. The fourth group contained G4 (L16B), G6 (L28A), G7 (L23A), G8 (L26A), G9 (L33A), G10 (LG1), G11 (LZB) and G12 (LBB). G5 was divided into 16 branches containing L16C, L18A, L19A, L28B, L29A, L21B, L22A, L22B, L24A, L25A, L30A, L34A, LEU, LCHIA, LCES1, LCES2, LG2 and LG3. The in-class variance value of G5 was calculated as 9.556. Some genotypes were separated according to their location records. In the analysis of variance for the best grouping, the values were calculated as $9.208(78.42 \%)$ within the group and $2.533(21.58 \%)$ among the groups. The total value was found to be 11.741 .

The IRAP dendrogram revealed presence of 4 groups (Fig. 4). The first group (G1) contained 26 genotypes (L2A, L11B, L17B, L17C, L18A, L19A, L28B, L29A, L21B, L22A, L22B, L23A, L24A, L25A, L26A, L30A, L33B, L34A, LEU, LCHIA, LCES1, LCES2, LG1, LG2, LG3, LZB), the second group (G2) contained six genotypes (L2B, L11A, L16A, L16B, 
L16C, L17A), the third group (G3) contained L28A and L33A genotypes, the fourth group (G4) contained only the LBB genotype. The variance values were calculated as $10.385(\mathrm{G} 1), 8.767(\mathrm{G} 2)$ and $4.000(\mathrm{G} 3)$. The variance values calculated for the best classification of the genotypes were found to be $9.918(92.19 \%)$ intra-group and $0.840(7.81 \%)$ among the groups, the total value being 10.758 .

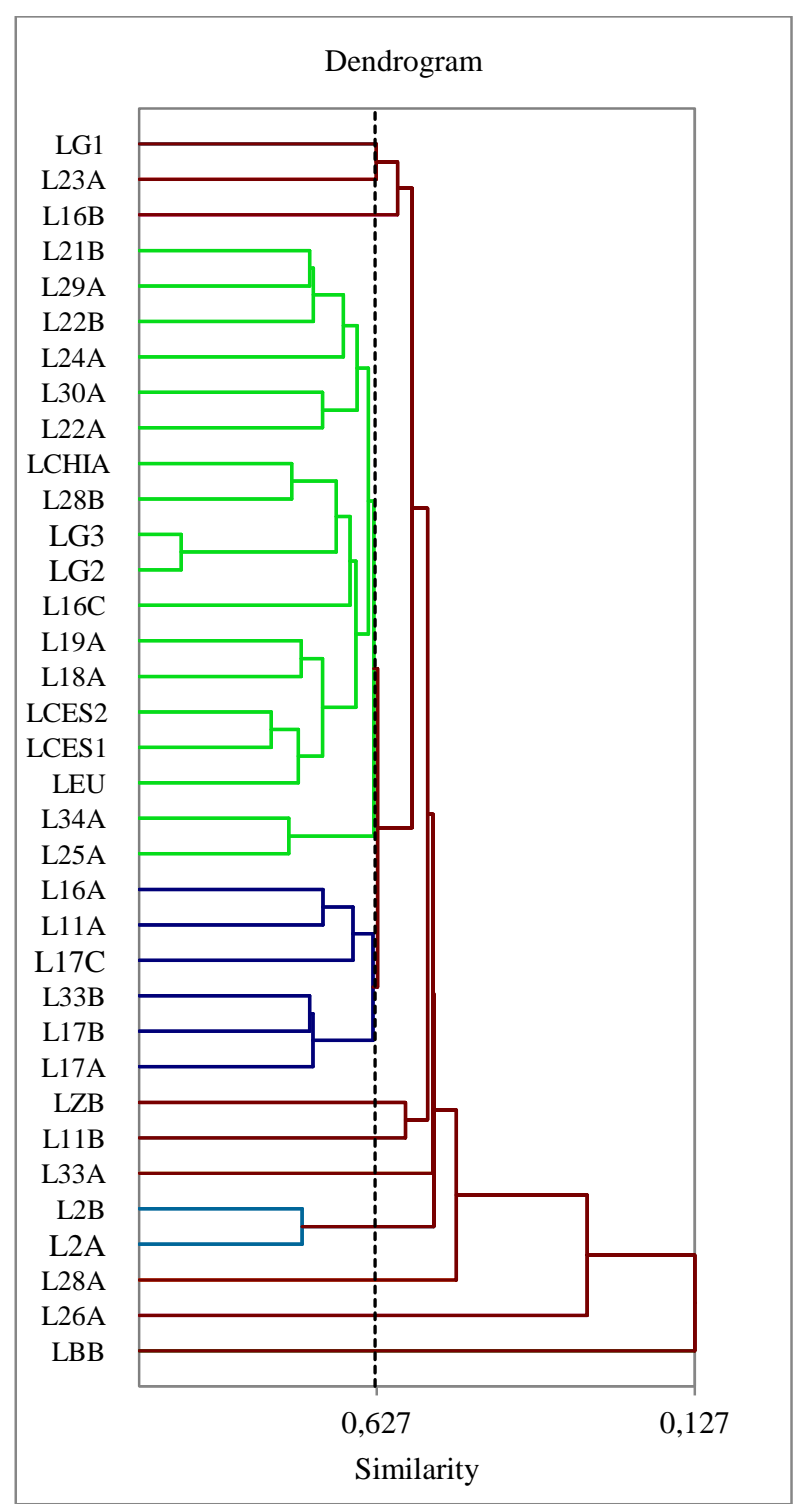

Fig. 3. UPGMA Dendrogram of $35 \mathrm{P}$. lentiscus specimens based on ISSR data.

Principle component analysis (PCA) was performed to assess the distribution patterns of the populations based on ISSR and IRAP marker systems (Fig. 5). The PCA results showed that the two axes (F1, 43.62\% and $\mathrm{F} 2,5.09 \%$ ) as the main component represented a total of $48.71 \%$ of the variation in the population. It appeared that there were 3 distinct groups. Two of the groups were the clusters of independent genotypes of LBB and L24A and one group was the sum of the other specimens. This last group, represented by a large number of genotypes, was divided into 4 subgroups among themselves.

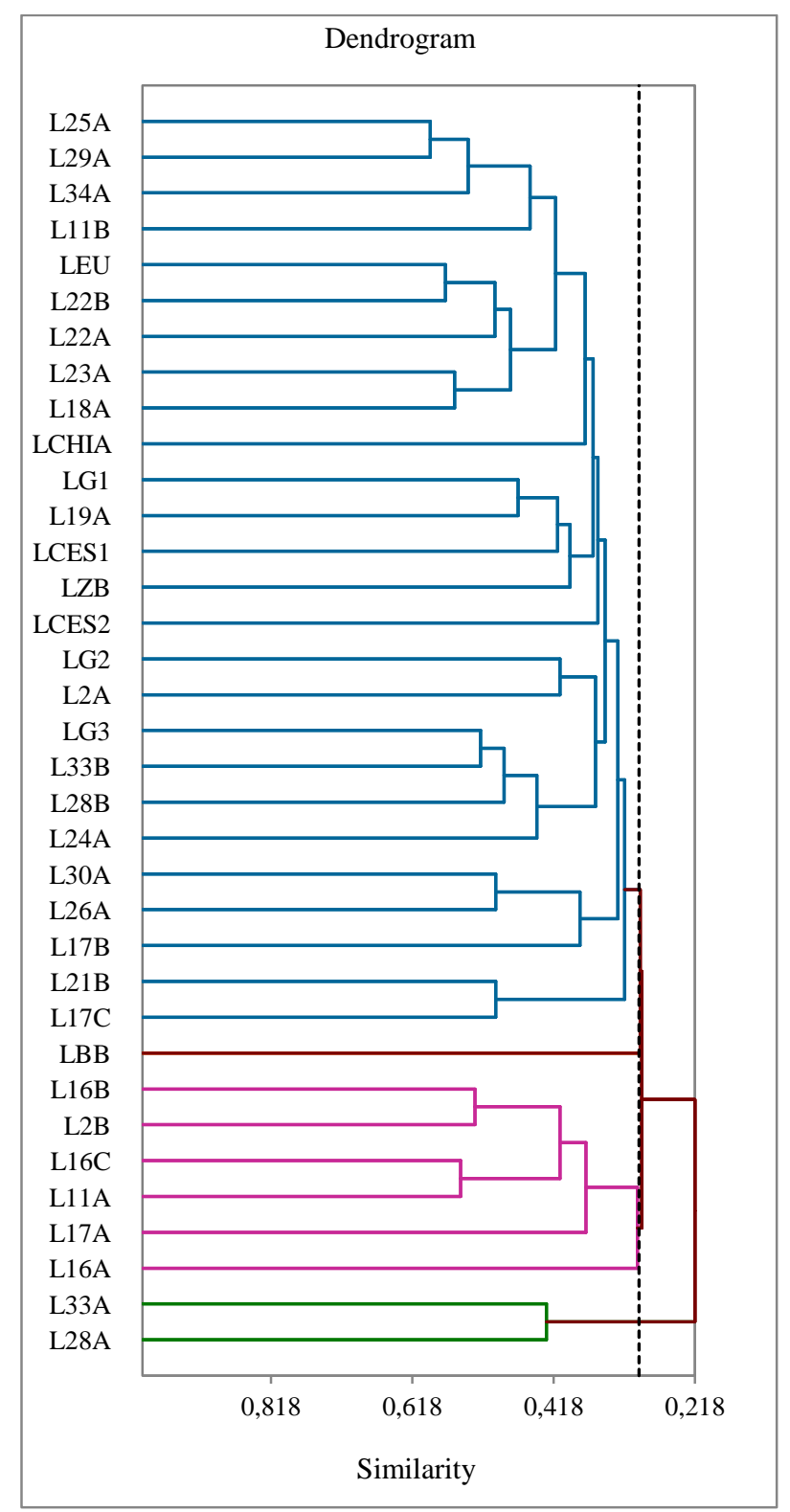

Fig. 4. UPGMA Dendrogram of 35 P. lentiscus speciemens based on IRAP data.

\section{Discussion}

The average PIC value was calculated as 0.458 according to the ISSR assay. If a PIC value is $>0.5$, then polymorphism is at a high level, while if it is between 0.25 and 0.5 , the polymorphism is normal. However, when the PIC value is 0.25 , it is necessary to mention the weakness of the polymorphism (Botstein et al. 1980). The highest genetic similarity was found between the Cretan genotypes (LG2 and LG3), indicating that the biogeographic distribution is the factor for microsatellite polymorphism. It was remarkable that the similarity between Çeşme culture varieties (LCES1-2) and Cretan samples (LG1-2-3) was 0.629, indicating the closeness of the phylogenetic and genetic relations. The similarity value was pointed to the biogeographic source of the material used in culture studies. LCHIA (Chios variety) also showed the highest similarity (0.760) to L28B (C1, 


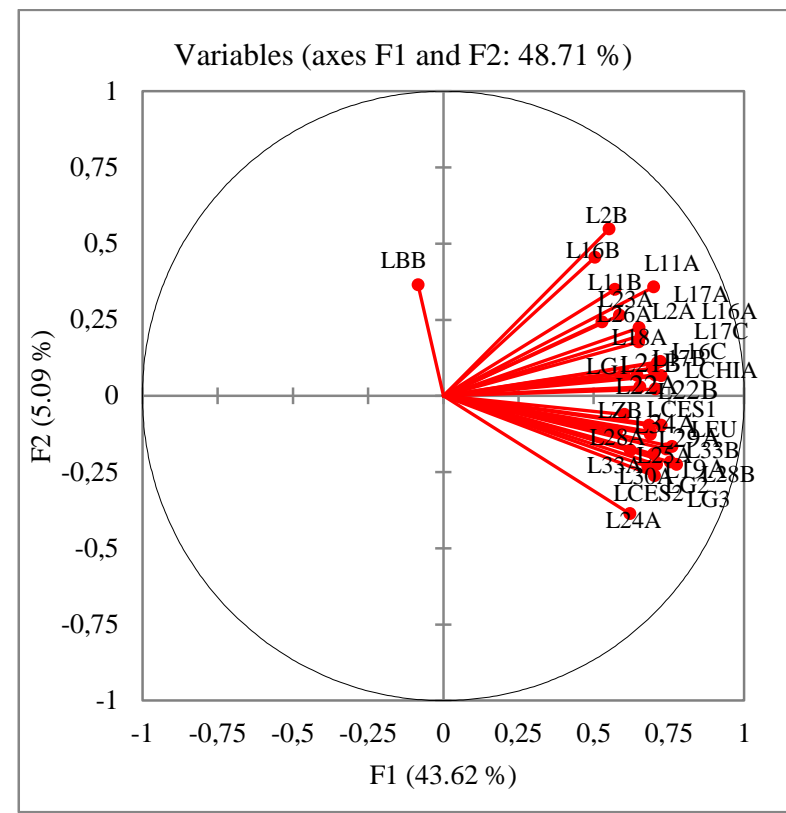

Fig. 5. PCA output of the populations based on ISSR and IRAP data.

Kıyıkışlacık village / Milas). The highest ISSR polymorphism of the L28B (wild genotype) may be due to the change in primer binding sites, the independent alleles to occur and mutations in the microsatellite gene (Freudenreich et al. 1997). The phylogenetic tree constructed with the ISSR data shows that the specimens are separated according to their biogeographic positions. From the phylogenetical data, it was observed that the genotypes were divided into 12 groups and 9 of them were independent branches in the dendrogram. It can be explained by the emergence of isolated and differentiated genotypes that grow in various habitat conditions as adapted ecotypes. In the study of Zografou et al. (2010), UBC842, UBC850 and UBC856 primers were used, and the similarity ratios ranged from $68 \%$ to $12.5 \%$. However, the similarity coefficient between the Chios varieties and the other specimens in our study was calculated between 0.760 and 0.093. This result indicates a wider distribution range compared to the results of Zografou et al. (2010). In another study with P. lentiscus (Abuduli et al. 2016), gene pool was investigated using SSR, RAPD and ISSR markers, and ITS regions in 24 different $P$. lentiscus wild genotypes, and the highest polymorphism was obtained by ISSR compared to other molecular markers (SSR, RAPD and ITS region) and the PIC value was calculated as 0.887 . In the study using ISSR, the genotypes examined were divided into 5 subpopulations. As a result, the use of the ISSR markers was demonstrated to be a useful tool for genetic diversity analysis in wild genotypes of $P$. lentiscus and in future breeding studies (Abuduli et al. 2016). Considering the genetic similarity rates of the intraspecific variation obtained by the IRAP method, it was determined that LG1 (Cretan) was the closest specimen to the LCHIA (Chios variety. In terms of genetic similarity, the nearest sample to LCHIA genotype was L26A (C1, Güvercinlik village / Bodrum, $3 \mathrm{~m})$ and the furthest sample was L33A (C2, sea edge, Göcek / Fethiye, 62m), showing that species locations along seaside or in the lower parts of the mountains were not effective for genetic similarity. The dendrogram of IRAP data was examined in order to evaluate phylogenetic relations and it was shown that 3 main groups and 1 genotype (LBB) were separated, and retrotransposon mobilities resulting in high polymorphism were affected by the geographical locations of the plant samples. The results of Kılınç et al. (2014) and Koç et al. (2014) on P. lentiscus based on IRAP and AFLP techniques were supported with the findings of amplification data obtained in our present study in relation to the LTR2 region. Kırdök \& Çiftçi (2016) used iPBS, REMAP and IRAP techniques of retrotransposon markers for genetic diversity analysis of Pistacia genus. They found high genetic similarity between $P$. vera - P. khinjuk, $P$. atlantica $-P$. mutica and $P$. terebinthus - P. palaestina and it was reported that the IRAP technique of retrotransposon-based DNA markers for 7 Mediterranean Pistacia species (total 35 samples) could be used in molecular characterization and molecular breeding trials (Kırdök \& Çiftçi 2016). In addition, retrotransposon marker systems have also been used in taxonomic studies of the Persian species of the genus Pistacia ( $P$. vera, $P$. khinjuk, $P$. atlantica) (Ghaemmaghami et al. 2013). In another study, IRAP analysis resulting in high polymorphism was performed on $P$. vera, $P$. khinjuk, $P$. eurycarpa and $P$. atlantica (Amirbakhtiar \& Sorkheh 2015). Genetic diversity analysis using SCoT and IRAP markers in wild Pistacia species found an average PIC value of 0.32 for IRAP (Sorkheh et al. 2016). In conclusion, the applications of molecular markers are useful not only in the intraspecific variations, but also in interspecific analysis of Pistacia species. In a study using RAPD and AFLP markers, Pistacia was divided into two groups in a dendrogram segregated as evergreen $P$. lentiscus and the other group as deciduous (Golan-Goldhirsh et al. 2004). UPGMA analysis using AFLP markers showed clustering of $P$. terebinthus with $P$. mexicana and $P$. lentiscus implying their phylogenetic relations (Kafkas 2006). Golan-Goldhirsh et al. (2004) also reported that close genetic relationships in Pistacia species gave more reliable results in sex taxonomy compared to morphological classification. In the present study, the PCA analysis identifed different groups of 35 accessions in close proximity to each other. The results from PCA analysis based on ISSR and IRAP data showed that the variation in the P. lentiscus gene pool in Anatolia was high, genotypes were separated as groups, geographically isolated accessions were clearly separated from the others, and geographically related specimens were grouped together. On the other hand, significant differences were calculated among the accessions based on morphological parameters. Supportingly, phytochemical and morphological characters of $P$. lentiscus genotypes collected from 
different locations (Spain, Tunisia, Cyprus and Israel) showed a tendency of high phenotypic variation (Barazani et al. 2003). The results obtained with the combination of the data produced by both marker systems revealed that the genotypes distributed in the Aegean region constitute separate groups.

\section{Conclusion}

Retrotransposon-based molecular markers produce high polymorphism and high solubility in identifications of plant genetic resources, determining the relationships between various plant groups and plant taxa of agricultural potential and the evolutionary history of plant genome (Gribbon et al. 1999). ISSR has been used successfully to analyze the level of genetic diversity within and between species in wild accessions (Reddy et al. 2002). In the present study, the high polymorphism in western Turkey genotypes of $P$. lentiscus determined at both morphological and molecular levels indicates that

\section{References}

1. Abuduli, A., Aydin, Y., Sakiroglu, M., Onay, A., Ercisli, S. \& Altinkut Uncuoglu, A. 2016. Molecular Evaluation of Genetic Diversity in Wild-Type Mastic Tree (Pistacia lentiscus L.). Biochemical Genetics, https://doi.org/10.1007/s10528-016-9742-0

2. Ak, B.E. \& Parlakçı, H. 2009. Pistacia lentiscus in the Mediterranean Region in Turkey. Acta Horticulturae, 818: 77-81.

3. AL-Saghir, M.G. 2010. Phylogenetic Analysis of the Genus Pistacia L. (Anacardiaceae) Based on Morphological Data. Asian Journal of Plant Sciences, 9(1): 28-35.

4. Amirbakhtiar, N. \& Sorkheh, K. 2015. DNA fingerprinting of wild Pistacia L. species germplasm in Iran using interretrotransposon amplified polymorphism (IRAP) marker. $1^{\text {st }}$ Intertational and $9^{\text {th }}$ National Biotechnology Congress of Islamic Republic of Iran 2425 May 2015, Tehran, Iran.

5. Balan, K.V., Prince, J., Han, Z., Dimas, K., Cladaras, M., Wyche, J.H., Sitaras, N.M. \& Pantazis, P. 2007. Antiproliferative activity and induction of apoptosis in human colon cancer cells treated in vitro with constituents of a product derived from Pistacia lentiscus L. var. chia. Phytomedicine, 14(4): 263-272. https://doi.org/ 10.1016/j.phymed.2006.03.009

6. Barazani, O., Dudai, N. \& Golan-Goldhirsh, A. 2003. Comparison of Mediterranean Pistacia lentiscus genotypes by random amplified polymorphic DNA, chemical, and morphological analyses. Journal of Chemical Ecology, 29(8): 1939-1952. https://doi.org/10.1023/A:1024862614345

7. Bhat, K.V. 2002. Molecular data analysis, Proceedings of the short-term training course on molecular marker application in plant breeding. ICAR, New Delhi.

8. Botstein, D., White, R.L., Skolnick, M. \& Davis, R.W. 1980. Construction of a genetic linkage map using restriction fragment length polymorphisms. The American Society of Human Genetics, 32: 314-331. this region is one of the important origin centers of $P$. lentiscus. In conclusion, the results of our study showed that $P$. lentiscus has high intraspecific variations for the wild genotypes in Anatolia and combined marker systems reveal high polymorphism and detailed phylogenetic relations in this species. More detailed investigations on molecular variation in the gene pool of this species are needed in a wider range of samples using various marker systems to provide molecular databases useful in agricultural rehabilitation programs and molecular taxonomic studies to identify infraspecific boundaries.

\section{Acknowledgement}

The authors thank to Res. Assist. Riza SERTTAS who assisted in the collection of the specimens. This research was financially supported by the Scientific Research Projects İstanbul University (İ̈BAP) with the Project No: 46474.

9. Correia, O.A. \& Catarino, F.M. 1994. Seasonal changes in soil-to-leaf resistance in Cistus sp. and Pistacia lentiscus. Acta Oecologica, 15: 289-300.

10. Fan, S., Xiao, Z., Tang, X., Chen, C., Zhang, Y., Deng, Q., Yao, P. \& Li, W. 2014. Inhibition effect of secondary metabolites accumulated in a pervaporation membrane bioreactor on ethanol fermentation of Saccharomyces cerevisiae. Bioresource Technology, 162: 8-13. https://doi.org/10.1016/j.biortech.2014.03.140

11. Freudenreich, C.H., Stavenhagen, J.B. \& Zakian, V.A. 1997. Stability of a CTG/CAG trinucleotide repeat in yeast is dependent on its orientation in the genome. Molecular and Cellular Biology, 17: 2090-2098.

12. Fritz, U., Kiroký, P., Kami, H. \& Wink, M. 2005. Environmentally caused dwarfism or a valid species - Is Testudo weissingeri Bour, 1996 a distinct evolutionary lineage? New evidence from mitochondrial and nuclear genomic markers. Molecular Phylogenetics and $\begin{array}{lll}\text { Evolution, } & 37(2): & 389-401 .\end{array}$ https://doi.org/10.1016/j.ympev.2005.03.007

13. Ghaemmaghami, L., Attar, F. \& Rahiminejad, M. 2013. Distinctness and Inter Relationships of Pistacia L. Species in Iran as Evidenced by Retroelement Insertional Polymorphisms (IRAP Method). Iranian Journal of Botany, 19: 78-85.

14. Golan-Goldrish, A., Barazani, O., Wang, Z.S., Khadka, D.K., Saunders, J.A., Kostiukovsky, V. \& Rowland, L.J. 2004. Genetic relationships among Mediterranean Pistacia species evaluated by RAPD and AFLP markers. Plant Systematics and Evolution, 246: 9-18.

15. Gribbon, B.M., Pearce, S.R., Kalendar, R., Schulman, A.H., Paulin, L., Jack, P.L., Kumar, A. \& Flavell, A.J. 1999. Phylogeny and transpositional activity of Ty1copia group retrotransposons in cereal genomes. Molecular Genetics and Genomics, 261: 883-891.

16. He, M.L., Li, A., Xu, C.S., Wang, S.L., Zhang, M.L., Gu, H., Yang, Y.Q. \& Tao, H.H. 2007. Mechanism of antiprostate cancer by gum mastic: NF-kappaB signal as target. Acta Pharmacologica Sinica, 28: 446-462. 
17. Jaccard, P. 1908. Nouvelles recherches sur la distribution florale. Bulletin de la Societe Vaudoise des Sciences Naturelles, 44: 223-270.

18. Kafkas, S. 2006. Phylogenetic analysis of the genus Pistacia by AFLP markers. Plant Systematics and Evolution, 262: 113-124.

19. Kafkas, S. \& Perl-Treves, R. 2001. Morphological and molecular phylogeny of Pistacia species in Turkey. Theoretical and Applied Genetics, 102(2001): 908-915. https://doi.org/10.1007/s001220000526

20. Kafkas, S. \& Perl-Treves, R. 2002. Interspecific Relationships in Pistacia Based on RAPD Fingerprint. HortScience, 37(1): 168-171.

21. Kalendar, R., Flavell, A.J., Ellis, T.H.N., Sjakste, T., Moisy, C. \& Schulman, A.H. 2011. Analysis of plant diversity with retrotransposon-based molecular markers. Heredity, 106(4): 520-530. https://doi.org/10.1038/hdy.2010.93

22. Kalendar, R., Grob, T., Regina, M., Suoniemi, A. \& Schulman, A.H. 1999. IRAP and REMAP: two new retrotransposon-based DNA fingerprinting techniques. Theoretical and Applied Genetics, 98: 704-711.

23. Kılınç, F.M., Süzerer, V., Çiftçi, Y.Ö., Onay, A., Yıldırım, H., Altınkut-Uncuoğlu, A., Tilkat, E., Koç, İ., Akdemir, Ö.F. \& Karakaş-Metin, Ö. 2014. Clonal micropropagation of Pistacia lentiscus L. and assessment of genetic stability using IRAP markers. Plant Growth Regulation, 75(1): 75-88.

24. Kırdök, E. \& Çiftçi, Y.Ö. 2016. Retrotransposon marker systems as a tool to analyze molecular diversity of Mediterranean Pistacia species. International Journal of Agriculture and Biology, 18: 601-606.

25. Koç, İ., Akdemir, H., Onay, H., Çiftçi, Y. 2014. Coldinduced genetic instability in micropropagated Pistacia lentiscus L. plantlets. Acta Physiologiae Plantarum, 36: 2373-2384. https://doi.org/10.1007/s11738-014-1610-0

26. Kokwaro, J.O. \& Gillet, J.B. 1980. Notes on the Anacardiaceae of Eastern Africa. Kew Bull, 34(1980): 745-760.

27. Kolano, B., Bednara, E. \& Weiss-Schneeweiss, H. 2013. Isolation and characterization of reverse transcriptase fragments of LTR retrotransposons from the genome of Chenopodium quinoa (Amaranthaceae). Plant Cell Reports, 32(10): 1575-1588. https://doi.org/10.1007/s00299-013-1468-4.

28. Lodhi, M.A., Ye, G.N., Weeden, N.F. \& Reisch, B.I. 1994. A Simple and Efficient Method for DNA Extraction from Grapevine Cultivars and Vitis Species. Plant Molecular Biology Reporter, 12(1): 6-13. https://doi.org/10.1007/BF02668658

29. Loutrari, H., Magkouta, S., Pyriochou, A., Koika, V., Kolisis, F.N., Papapetropoulos, A. \& Roussos, C. 2006.
Mastic oil from Pistacia lentiscus var. chia inhibits growth and survival of human $K 562$ leukemia cells and attenuates angiogenesis. Nutrition and Cancer, 55(1): 8693. https://doi.org/10.1207/s15327914nc5501_11

30. Ma, D., Amonlirdviman, K., Raffard, R.L., Abate, A., Tomlin, C.J. \& Axelrod, J.D. 2008. Cell packing influences planar cell polarity signaling. Proceedings of the National Academy of Sciences USA, 105(48): 1880018805 .

31. Nagy, Z.T., Joger, U., Guicking, D. \& Wink, M. 2003. Phylogeography of the European whip snake Coluber (Hierophis) viridiflavus as inferred from nucleotide sequences of the mitochondrial cytochrome-b gene and ISSR genomic fingerprinting. Biota, 3: 109-118.

32. Parfitt, D.E. \& Badenes, M.L. 1997. Phylogeny of the genus Pistacia as determined from analysis of the chloroplast genome. PNAS, 94 (1997): 7987-7992.

33. Park, J.K., Liu, X., Strauss, T.J., McKearin, D.M. \& Liu, Q. 2007. The miRNA pathway intrinsically controls selfrenewal of Drosophila germline stem cells. Current Biology, 17(6): 533-538. https://doi.org/10.1016/j.cub.2007.01.060

34. Reddy, M.P., Sarla, N. \& Siddiq, E.A. 2002. Inter simple sequence repeat (ISSR) polymorphism and its application in plant breeding. Euphytica, 128: 9-17. https://doi.org/10.1023/A:1020691618797

35. Sorkheh, K., Amirbakhtiar, N. \& Ercisli, S. 2016. Potential Start Codon Targeted (SCoT) and Interretrotransposon Amplified Polymorphism (IRAP) Markers for Evaluation of Genetic Diversity and Conservation of Wild Pistacia Species Population. Biochemical Genetics, https://doi.org/10.1007/s10528016-9725-1

36. Stevens, P.F. 2008. Angiosperm phylogeny website Version 9(2008): 1-2.

37. Tenaillon, M.I., Hufford, M.B., Gaut, B.S. \& Ross-Ibarra J. 2011. Genome Size and Transposable Element Content as Determined by High-Throughput Sequencing in Maize and Zea luxurians. Genome Biology and Evolution, 3: 219-229. https://doi.org/10.1093/gbe/evr008

38. Whitehouse, W.E. 1957. The Pistachio nut- a new crop for the western United States. Economic Botany, 11(4): 281-321.

39. Yaltirik, F. 1967. Pistacia L., Flora of Turkey, In: Davis, P.H. (ed.), Cilt 2, Edinburgh At The University Press, Edinburgh, 554 pp.

40. Zografou, P., Linos, A. \& Hagidimitriou, M. 2010. Genetic diversity among different genotypes of Pistacia lentiscus var. chia (mastic tree). Options Méditerranéennes, 94: 159-163.

41. Zohary, M. 1952. A monographical study of the genus Pistacia. Palestine Journal of Botany, 5(4): 187-228. 
